\section{MOVING? MARRYING? CHANGING POSITIONS?}

Please keep ALA informed when you change your address, your name, or your position.

If you cannot locate your current membership card or seem to have missed issues of your membership publications, please notify ALA.

Remember, it takes several weeks for records changes to become effective. During this period, mail will be sent to your former address.

For any membership records changes or problems, please write:

Membership Records

American Library Association

50 East Huron Street

Chicago, Illinois 60611

\section{MIDWEST ACADEMIC LIBRARIANS}

Midwest Academic Librarians conference will meet on May 5 and 6 at University of Illinois Chicago Circle campus. Giles B. Robertson and Louis A. Schultheiss have arranged the program.

\section{May 5, 1967}

A.M. Tours of the campus and the library

2:00 P.M. James Lundy, President, University Microfilms

The Future of Inter-Relationships Between the Photocopying Industry and College and University Libraries.

6:00 P.M. Walter Netsch, Skidmore, Owens, \& Merrill

"Transition in Library Design Since World War II and Its Implications for the Future."

$$
\text { May 6, } 1967
$$

9:30 A.M. "The Library of Congress MARC Project."

Mrs. Henriette Avram, Director of the Project, and others

12:00 Luncheon, Frazer Poole-Summary of the Meeting

Requests for further information and reservation blanks should be addressed to Mr. G. B. Robertson, University Library, University of Illinois at Chicago Circle, Box 8198, Chicago, Ill. 60680 .

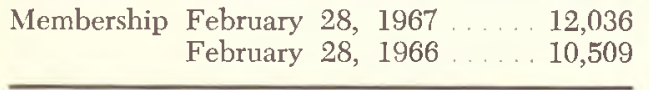

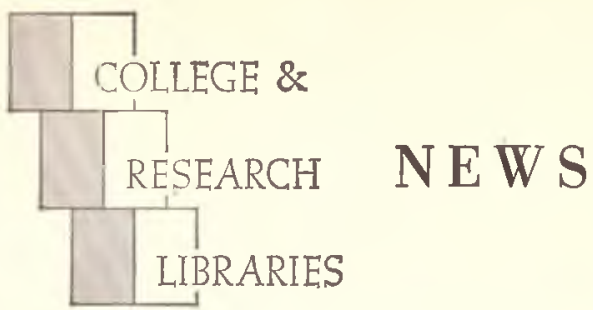

ACRL News Issue of College \& Research Libraries

Editor, David Kaser, Joint University Libraries, Nashville, Tenn. 37203.

Publications Officer, Mary Falvey, 50 E. Huron St., Chicago 60611.

ACRL Executive Secretary, George M. Bailey.

ACRL Officers, 1966/67: President, Ralph E. McCoy; College Libraries Section Chairman, Lee Sutton; Junior College Libraries Section, Harriett Genung; Rare Books Section, William H. Runge; Subject Specialists Section, Mary E. Schell; Agriculture and Biological Sciences Subsection Chairman, Roy L. Kidman: Art Subsection, Mrs. Kathryn Blackwell; Law and Political Science Subsection, Jane Wilson; Slavic and East European Subsection, Bohdan S. Wynar; University Libraries Section Chairman, John M. Dawson.

Editorial Board: John M. Dawson, University of Delaware; Gustave A. Harrer, Boston University; SAMUEL ROTHSTEIN, University of British Columbia; JAmes E. SkIPpEr, Association of Research Libraries; Norman E. Tanis, Kansas State College of Pittsburg; Maurice F. Tauher, Columbia University; Eifeen Thornton, Oberlin College.

News from the Field, Personnel profiles and notes, classified advertising, official matter of ACRL, and other material of a timely nature is published in the News issues of College of Research Libraries.

Inclusion of an article or advertisement in $C R L$ does not constitute official endorsement by ACRL or ALA.

Production and Advertising and Circulation office: $\mathbf{5 0}$ E. Huron St., Chicago, IIl. 60611. Change of address and orders for subscriptions should be addressed to College of Research Libraries, for receipt at the above address, at least two months before the publication date of the effective issue.

Subscription to $C R L$ is included in membership dues to $A C R L$ of $\$ 6$ or more; other subscriptions to $C R L$ are \$10 per year. Neither subscriptions nor memberships include miscellaneous unscheduled supplements, which are available by purchase only. Retroactive subscriptions are not accepted. Single journal copies are available at $\$ 1.50$ each and News issues at $\$ 1.00$ each from ALA Publishing Department.

Indexed in Library Literature. Abstracted in Library Science Abstracts. Book reviews indexed in Book Review Index.

College of Research Libraries, is the official journal of the Association of College and Research Libraries, a division of the American Library Association; and is published seventeen times per year-bi-monthly as a technical journal with 11 monthly News issues, combining July-August-at 1201-05 Bluff St., Fulton, Mo. 65251 .

Second-class postage paid at Fulton, Mo. and at additional mailing offices. 